\title{
不動産関係判例の動き [14]
}

概 況

今回は, 判例時報1259 1270号, 判例タイムズ 655〜665号の中から，8件の判決例を選んだ。そ のうち, 担保をめぐる 3 件の最高裁判決が注目さ れる。 $1 ， 2$ は譲渡担保に関する最高裁判決であ り，譲渡担保の法的性質を考えるうえでも参考に なるものである。 3 は抵当権と農地の賃貸借との 関係に関する最高裁判決である。 4 は抵当権と法 定地上権， 5,6 は取得時効， 7 は原野商法, 8 は 営業用店舗の賃貸借契約の各事例である。

\section{1. 譲渡担保（不動産）}

\section{土地建物所有権移転登記抹消登記手続等請求事}

件

最高裁昭和62.11.12判決（第 1 小法廷），上告棄 却, 判時1261-71, 判夕655-106

本件は, 不動産譲渡担保について, 被担保債権 の弁済がなされた後に譲渡担保権者が目的不動産 を売却してしまった場合, 買主は譲渡担保設定者 に対し所有権の取得を主張できるかどうかが問題 となった事案である。本最高裁判決は, 本件の場 合を不動産が二重譲渡された場合と同様に捉え,

譲渡担保設定者は，第三者である買主より先に登 記を譲渡担保権者から経由していなければ所有権 の復㴆を第三者に主張できないとした。判旨は次 の通り。

「不動産が譲渡担保の目的とされ，設定者から 譲渡担保権者への所有権移転登記が経由された場 合に拈いて, 被担保債務の弁済等により譲渡担保

\section{不動産判例研究会}

権が消滅した後に目的不動産が譲渡担保権者から 第三者に譲渡されたときは，右第三者がいわゆる 背信的悪意者に当たる場合は格別，そうでない限 り, 譲渡担保設定者は登記がなければその所有権 を右第三者に対抗するととができないものとする のが相当である。」

譲渡担保结, 担保の方法として, 目的物の所有 権を相手方に移転するものである。民法典など法 律上明示された担保方法ではなく, 判例法によっ て認められている取引慣習上のものであるため, その法的性質について考え方が分かれている。学 説上は，法的性質につき譲渡担保の形式を重視す る所有権的構成から担保としての実質を重視する 担保権的構成へと変化してきたという捉え方が有 力である。しかし，判例に执いては必ずしもとの 点を明言して扔らず，所有権的構成に依拠したと 思われる判決もいくつか出されている。てのよう な状況のなかで, 本判決は, 二重譲渡に扣ける対 抗力の問題として捉えて問題を処理した。判旨は, 譲渡担保の法的性質については直接触れていない が，担保方法としての所有権移転及び登記の経由 という形式を重視したものと捉えるととは可能で ある。

\section{2. 譲渡担保（集合物）}

\section{第三者異議事件}

最高裁昭和62.11. 10判決 (第 3 小法廷), 上告棄 却, 判時1268-34, 判夕662-67

譲渡担保の目的物が集合物である場合には, 譲 渡担保の一般的問題に加えて, 集合物に係る問題 
が生ずる。本件は，てのような問題について最高 裁判所の基本的な考元方を示したものであり, 理 論上, 実際上重要な意味を有する。事案は, Y 社 (上告会社) がA社に対し棒銅等を売却し，その 代金の回収を図るため動産売買の先取特権に基づ き，A社倉庫に搬入された同棒鋼等につき動産競 売の申立をしたため, 同棒鋼等を含む在庫商品一 切につき根譲渡担保権を有するX社(被上告会社) が, 同競売手続の不許を求めて第三者異議の訴え を提起したものである。第一審, 第二審はX社の 請求を認めた。Y社は上告したが，本判決は次の ように述べ，上告学棄却した。

「構成部分の変動する集合動産であっても, そ の種類, 所在場所及び量的範囲を指定するなどの 方法によって目的物の範囲か㣥定される場合に は， 1 個の集合物として譲渡担保の目的とするて とができるものと解すべきであるてとは，当裁判 所の判例とするとてろである(昭和53年(才)第925号 同54年 2 月 15 日第 1 小法廷判決・民集 33 巻 1 号 51 頁参照)。そして，債権者と債務者との間に，右 のような集合物を目的とする譲渡担保設定契約が 締結され，債務者がその構成部分である動産の占 有を取得したときは債権者が占有改定の方法によ ってその占有権を取得する旨の合意に基づき，債 務者が右集合物の構成部分として現に存在する動 産の占有を取得した場合には, 債権者は, 当該集 合物を目的とする譲渡担保権につき対抗要件を具 備するに至り, この対抗要件具備の効力は, その 後構成部分が変動したとしても, 集合物としての 同一性が損なわれない限り，新たにその構成部分 となった動産を包含する集合物について及ぶもの と解すべきである。したがって，動産売買の先取 特権の存在する動産が右譲渡担保権の目的である 集合物の構成部分となった場合に扣いては，債権 者は，右動産についても引渡を受けたものとして 譲渡担保権を主張するととができ，当該先取特権 者が右先取特権に基づいて動産競売の申立をした ときは, 特段の事情のない限り, 民法 333 条所定
の第三取得者に該当するものとして，訴えをもっ て右動産競売の不許を求めるととができるものと いうべきである。」

本判決は, 集合物譲渡担保の判例法上の処理を 明確にし，実務の法的安定に資するものとして評 価するととができる。

\section{3. 抵当権と賃借権}

\section{賃貸借契約解除請求事件}

最高裁昭和63.2.16判決(第 3 小法廷), 上告棄却, 判時1270-84

民法 395 条は, 短期賃貸借（民法 602 条に規定 されている）は抵当権の登記後に登記したもので も抵当権者に対抗するてとができるが(本文)，そ の賃貸借が抵当権者に損害を及ばすときは裁判所 は抵当権者の請求によりその解除を命ずるととが できる(但書) と規定する。本件は，農地の抵当 権者に対抗するてとができないその農地の貢借権 が，農地法 3 条 2 項 1 号の規定により実質的には 対抗力ある賃借権と同様抵当権者に損害を及ぼす 場合に，この但書の規定を準用して，賃貸者の解 除請求を認めた事例である。判旨は次の通り。

「本来，抵当権者に対抗することができない賃 貸借は，競売手続に执いて競落人に対抗するとと ができないものとしててれを無視して右競売手続 を進行すればよいのであって，抵当権者に対抗す るととができる短期賃貸借であってそれが抵当権 者に損害を及ぼすときにのみ前記のと扣り抵当権 者は民法 395 条但書により裁判所に対し右賃貸借 の解除を請求することができるのであるが，抵当 権者に対抗するととができない農地の賃貸借であ っても，本件のように競売手続上農地の賃借人の 地位が重視され，所轄農業委員会等により当該顀 借人（小作人）以外の者に競買適格証明書を交付 しない取扱いがされているため競買申出人が右賃 借人（小作人）に限定され，乙の点に打いて実質 的にはあたかも右賃貸借が抵当権者に対抗するこ とができるのと同様の状態をもたらし，その結 
果，抵当権者に損害が及ぶときに限り，抵当権者 は，同条但書を準用してかかる賃貸借の解除を請 求するととができるものと解するのが相当であ る。」

\section{4. 抵当権と法定地上権}

\section{壳却許可決定に対する執行抗告事件}

東京高裁昭和63.2.19決定, 取消, 判時1266-25

同一所有者に属する土地とその地上の木造建物 （木造亜鉛メッキ鋼板莫 2 階建）に共同根抵当権 が設定されたのち同建物が滅失し，第三者により 堅固建物（鉄骨造陸屋根 3 階建）か湕築された場 合に，旧建物を基準とした内容の法定地上権（民 法 388 条) の成立を認めた事例。本決定は，その 理由として，土地抵当権は土地から旧建物のため の地上権を控除した価值をその目的としているこ とを挙げている。

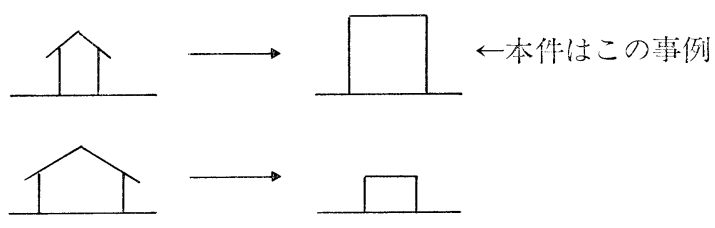

本件に扔いて新旧建物の床面積は次のように変 化した。すなわち, 旧建物は 1 階79.30平方メート ル，2 階78.16平方メートル，新建物は 1 階98.59 平方メートル，2 階88.23平方メートル，3 階55. 42平方メートルである。

民法 388 条に定められた法定地上権の成立要件 は, 判例・学説によって緩和され, 法定地上権の 成立が広く認められてきた。本決定もその流れの 一つとして位置づけるととができる。他方，法定 地上権の内容については，本決定のように旧建物 を基準とすべきか，あるいは新建物を基準（最高 裁昭和52.10.11判決，民集31-6-784）とすべきか は問題のあるとてろである。
5. 取得時効

\section{建物収去土地明渡請求事件}

最高裁昭和62. 6. 5判決, 上告棄却, 判時1260-7

他人の土地所有者と称する者との間で締結され た賃貸借契約に基づき，貢借人が，平穏公然に土 地の継続的な用益をなし，かつ，賃料の支払を継 続している場合に打いて，本件土地の継続的な用 益は賃借の意思に基づくものであるてとが客観的 に表現されているものと認めるてとができるとし て, 民法 163 条（所有権以外の財産権の取得 時 効）の規定に基づき, 土地賃借権の時効取得を認 めた事例。判旨は次の通り。

「他人の土地の継続的な用益という外形的事実 が存在し，かつ，その用益が賃借の意思基づく ものであるととが客観的に表現されているときに は，民法 163 条により，土地の賃借権を時効取得 するものと解すべきととは，当裁判所の判例とす るところであり（昭和 42 年(才)第 954 号同 43 年10月 8 日第 3 小法廷判決 ·民集 22 巻 10 号 2145 頁，同51 年(才)第 996 号同52年 9 月 29 日第 1 小法廷判決・裁 判集民事 121 号 301 頁)，他人の土地の所有者々称 する者との間で締結された貨貸借契約に基づい て，賃借人が，平穏公然に土地の継続的な用益を し，かつ，梖料の支払を継続しているときには， 前記の要件を満てすものとして，賃借人は，民法 163 条所定の時効時間の経過により, 土地の所有 者に対する関係に打いて右土地の賃借権を時効取 得するに至るものと解するのが相当である。」

6. 取得時効

\section{土地所有権移転登記手続請求控訴事件}

浦和地裁昭和 62. 5.29 判決, 控訴棄却 - 一部変更 (上告), 判時1259-89

取得時効進行中に原権利者加引当該不動産を譲 り受け，移転登記を経由した者に対し民法 162 条 2 項の 10 年の短期時効取得を援用しうる者がこれ を援用せず同条 1 項の 20 年の長期時効取得を援用 
するととができるとし，時効による所有権取得を 対抗できるとした事例。本判決は同趣旨の判断を した大審院昭和15年11月20日判決（法律新聞4646 号10頁)を引用した。

\section{7. 原野商法と不法行為責任}

\section{損害賠償請求事件}

京都地裁昭和62. 3.31判決, 認容(確定), 判夕 655 $-197$

いわゆる原野商法に係る損害賠償請求事件。被 告ら（不動産会社 $\mathrm{Y}_{1}$ 及び実質的経営者である代表 取締役 $\left.Y_{2}\right)$ が, 北海道南部地域の土地を, 極めて 価值が低く，将来も急激な值上がりが到底望めな いととを知りながら原告らに売却した場合につい て，売買代金名のもとに代金相当額を詐取してい たと認め，不法行為に基づく損害賠償として同売 買代金相当額の賠償責任を認めた事例。

$\mathrm{Y}_{2}$ は，買主らに対し，「北海道は年々開発さ れ，被告会社が北海道南部地区に所有している物 件は，大手の企業の工場誘致等で，地価の值上が りが期待できる。今，被告会社の土地を買って打 けば必ず儲かる。被告会社が，大企業等の買手を 探し，まとめて有利な条件で転売する。3 年持っ てもらえれば，他へ責任をもって買值の40パーセ
ント以上の值で転売してあげる。それが出来ない 場合でも被告会社が40パーセントの利息を付けて 顧客が被告会社から購入した土地を買い戻す」と 説明していた。

\section{8. 営業用店舗の貨貸借契約}

\section{建物明渡等請求控訴事件}

東京地裁昭和62. 2. 25判決, 取消・上告後和解, 判 夕 $657-134$

木造 2 階建の営業用店舗（東京都港区所在）の 賃借人（被控訴人）が，本件建物の老朽化を主た る理由として賃貸人（控訴人）加ら明渡しを求め られた調停事件の手続進行中に, 賃貸人に無断 で, 本件建物部分の老朽化の程度に重要な影響を 及ぼすような大規模な補修工事に着手し，西側外 壁と南側外壁の補修工事をした場合について，賃 貸人と貨借人との間の信頼関係が破壞されたとし て，賃貸借契約の解約を認めた事例。本件建物は 遅くとも大正 8 年頃 建築され, 屋根, 2 階の天 井, 床, 大部分の柱恓西に傾き, 柱, 梁及び外壁 の羽目板等の腐朽が相当進み, 空枠や壁の羽目板 や隙間から雨か吹き込むとともあったという状況 であった。 